\title{
TERRAS E DOAÇÕES - IGREJAS, IRMANDADES E IMIGRANTES POLONESES NO PARANá ${ }^{1}$
}

\author{
José Adilson Campigoto* \\ ja.cam.pi@hotmail.com \\ João Carlos Corso** \\ corso@irati.unicentro.br \\ Rejane Klein*** \\ rejane_klein1@hotmail.com
}

RESUMO: questões relativas ao uso e posse de terras são abordadas nesta pesquisa tendo, como foco de interesse, certas doações realizadas pelo Estado ou por proprietários particulares, em vista da construção de templos e outras destinações religiosas. O ponto de partida é a Irmandade de São José da Água Branca, São Mateus do Sul, PR, criada numa colônia basicamente de poloneses, para, entre outras obrigações, responsabilizar-se pelo 'espaço do culto'. Por se tratar de um recorte temático, fazemos um percurso desde o Brasil colonial até meados do século XX; percorremos, igualmente, outros estados brasileiros, embora o enfoque esteja na região centro sul do estado do Paraná. Podemos concluir, através dessa pesquisa, que tal irmandade situa numa região densa da história, conectando aspectos da vida cultural, religiosa e política do país. Está vinculada à etnicidade, ao povoamento, aos rituais, à organização dos homens e mulheres do campo e da cidade, por fim, à ruralidade brasileira.

PALAVRAS-CHAVE: Colonização; imigração polonesa; irmandades; região densa.

A Irmandade de São José é uma entidade constituída numa região de imigração majoritariamente polonesa e sediada na “... Colônia Água Branca, município de São Mateus do Sul - PR". ${ }^{2}$ O regulamento dessa instituição, que se estabelece como uma das principais fontes para o presente estudo indica a existência de um fundo social constituído por jóias, doações e imóveis. Prescreve que a finalidade dessa organização consiste em: levar os associados a exercitar a piedade, a praticar a caridade, a promover o culto a São José e a estimular a vida cristã. A irmandade também tem o escopo de regulamentar o uso da luz (velas) nos ofícios e a obrigação de mandar dizer missas em louvor a São José e pelas almas dos mortos. O artigo sétimo preceitua que " $A$

\footnotetext{
* Doutor em História Cultural pela UFSC. Vinculado à Universidade Estadual do Centro Oeste do Paraná. ** Doutor em História pela UFPR. Vinculado à Universidade Estadual do Centro Oeste do Paraná.

***Doutora em Educação pela UFSC. Vinculada à Universidade Estadual do Centro Oeste do Paraná
} 
irmandade conservará, não podendo alienar, nem transferir a terceiros sob qualquer pretexto: os terrenos, lotes que pertencem e nos quais está construída a Igreja e outras edificações". (ESTATUTO, Art. 7).

O artigo sétimo chama mais a atenção do que os seis precedentes por se tratar de matéria, à primeira vista, ambígua. O documento foi registrado em cartório público na data de quinze de maio do ano de dois mil. Nele, consta que a irmandade conservará os lotes da Igreja, entre os quais aquele em que o templo está construído. O referido edifício é considerado, atualmente, como um dos principais símbolos da imigração polonesa na região Centro Sul do Paraná.

Consta no mesmo documento que esta agremiação religiosa deverá conservar, igualmente, os lotes que pertencem e nos quais estão construídas outras edificações adjacentes ao lugar do culto. A irmandade não pode aliená-los nem transferi-los a terceiros.

Atualmente, a tarefa da conservação de terrenos e lotes não parece matéria usual no âmbito das normas e estatutos de associações. Tampouco frequente é a presença de irmandades religiosas em regiões classificadas como áreas de imigração de povoamento, especificamente, este movimento migratório iniciado no século XIX, constituído por gente oriunda da Europa central. Não é habitual encontrar tais confrarias e, muito menos, em se tratando de área da imigração, diremos, 'eslava'.

Esse tipo de agremiação é mais frequentemente vinculado, na historiografia brasileira, ao mundo do trabalho urbano e às corporações de ofício. No caso da figura de São José, a conexão seria quase que imediata, uma vez que tal santo, tradicionalmente, liga-se à atividade da construção e aos profissionais do ramo da carpintaria.

Com efeito, a irmandade de São José parece um elemento deslocado na história da imigração polonesa, ainda mais, quando consideramos a circulação de certo discurso ${ }^{3}$ aproximando a presumível identidade dos poloneses imigrados "... com o meio rural" (DOUSTDAR, 1990, p. 44). O mesmo autor, por exemplo, elencou variada literatura em que essa população, originária da região em que atualmente se localiza a Polônia, gente que teria “... certa aversão pelo quadro urbano” (DOUSTDAR, 1990, p. 44). Podemos dizer que, além disso, associam-se a eles certas imagens relativas a um pressuposto “... baixo índice de instrução” (DOUSTDAR, 1990, p. 44).

A criação dessa irmandade sob o patrocínio de um santo vinculado ao mundo urbano, no interior do estado do Paraná, supostamente no final do século XIX, num assentamento rural de imigrantes poloneses torna-se um acontecimento intrigante. 
Primeiramente, então, porque as associações de artesãos vinculam-se à história da urbanização enquanto, aqui, estaríamos falando de colonização. $\mathrm{O}$ vínculo historiográfico entre os artesãos e a história urbana é de abundante referência. ${ }^{4}$ Podemos citar, entre outros, os estudos de Hilário Franco Jr (2001), Marc Bloch (s.d.), Jacques Le Goff (2003), Genevieve D'haucourt (1988), Georges Duby (1994), Eric J. Hobsbawm (2008) e Leo Huberman (1986).

Silva e Assis (2007, p.02) afirmam que

No século XIV, devido principalmente a uma crescente urbanização, os artesãos passam a corresponder a uma nova força social. Os mestres estavam ligados inicialmente a atividades voltadas para a alimentação, como os carniceiros, a construção, como pedreiros, carpinteiros e taipadores, ao vestuário, alfaiates, sapateiros, jubiteiros, soqueiros, chapineiros, e também as armas e profissões, entre os quais, os armeiros, alfagemes, seleiros e ferreiros.

As corporações de artesãos podem ser vinculadas ao ambiente urbano, mas as irmandades não estavam restritas às fronteiras do 'mundo do trabalho'. Os autores acima citado escreveram que

Ao longo do século XVI os artífices de cada ofício seguiam impreterivelmente a um regimento, exceto se essa profissão não fosse regularizada e não possuísse regimento, além disso, essas profissões ou agrupamentos de ofícios possuíam também uma bandeira e no plano mais ligado ao sócio-religioso que ao profissional, os artífices participavam de uma irmandade ou confraria. (SILVA e ASSIS, 2007, p. 3).

As confrarias e irmandades podem ser caracterizadas, deste modo, por vínculos singulares estabelecidos no âmbito do que estamos denominando como campo ‘sociorreligioso'. Vera Lúcia Braga de Moura (2003) pesquisou esta faceta do fenômeno assinalando que, desde muito cedo, os membros das 'comunidades cristãs' praticavam o que se chamou de entre ajuda. Em se tratando da Europa no século XV, demarcou-se uma nova etapa dessa ordem de atividades. É o surgimento das casas de misericórdia. Por exemplo,

Em Portugal, foi criada, em 15 de março de 1498, uma casa para sustentar as viúvas em nome da Misericórdia. Este processo difundiu-se em todo seu reino ultramarino. No Brasil, em 1543, criava-se em Santos a primeira Misericórdia. Em 1560, criou-se a Santa Casa de Misericórdia de Olinda, que posteriormente entra em decadência, fundando-se em 1862 a Santa Casa de Misericórdia do Recife. (MOURA, 2003, p. 13).

Os estritos vínculos que se estabelecem entre as confrarias e irmandades e a história das Santas Casas de Misericórdia merecem um estudo à parte. Pressupomos, no 
entanto, que estas Casas, pelo menos em sua maioria, podem ter-se originado de irmandades e que são criadas em vista do cuidado do corpo, ou seja, visando a cura de doenças e/ou a promoção da saúde. A irmandade de São José da Água Branca, todavia, foi instituída, entre outras coisas, para a conservação, ou digamos o cuidado com os 'lotes'. Deste ponto de vista, não se trata de exercício da filantropia; mas será necessário reconhecer que a prática da caridade figura entre os objetivos a que se destina essa instituição criada na antiga Colônia de Água Branca. Pelo menos em termos de finalidade, trata-se de um vínculo importante.

Além dessa conexão ao campo sociorreligioso, as irmandades criadas no Brasil, frequentemente, são ligadas à história da conquista e da afirmação da liberdade dos africanos escravizados e dos afrodescendentes. Alguns pesquisadores chegam a estabelecer relações estreitas entre aumento do número de escravos e a ampliação da quantidade de irmandades instituídas em determinados períodos. Tal é o caso ilustrativo do Sergipe na última metade do século XVIII. Naquele estado, nota-se a presença intensa das irmandades, possivelmente, criadas por negros.

Entre essas estavam a de Nossa Senhora do Rosário dos Homens Pretos de São Cristóvão, Lagarto, Estância, Santo Amaro, Vila Nova e Rosário do Catete foram criadas nesse período. A de São Cristóvão teve seu compromisso aprovado em 1769, a Lagarto em 1771, Estância em 1772, a de Santo Amaro teve seu compromisso enviado para a Mesa de Consciência e Ordens em 1783 e recebeu a provisão do Arcebispado da Bahia em 1786, a de Vila Nova teve seu estatuto foi aprovado em 1800, por fim a de Rosário do Catete prestava contas desde 1779. (CUNHA, $2011 \mathrm{~S} / \mathrm{N})$.

Os números assim apresentados, por um lado, evidenciam as relações estabelecidas pelos estudiosos do assunto entre: as irmandades, o mundo do trabalho urbano, a religiosidade popular afro-brasileira e a filantropia. Por outro lado, torna ainda mais intrigante a criação de uma irmandade formada por colonos poloneses. Por se tratar de acontecimento pouco usual, buscaremos relacionar a confraria de São José às suas congêneres do período colonial brasileiro.

A articulação entre as temáticas acima apontadas e os dados quantitativos evidencia os vínculos que podemos estabelecer em termos de temporalidade. A respeito do tema e tendo por fundamento os resultados de pesquisas já consagradas e desenvolvidas por pesquisadores de reconhecida influência nesta área tais como Riolando Azzi e de Eduardo Hoornaert. Na concepção de Martins e Oliveira (2009) no período colonial brasileiro: 
Havia dois tipos principais de confrarias: as irmandades e as ordens terceiras. Ambas tinham como objetivo a promoção de cultos a um santo, a construção de oratórios, ermidas e capelas. Os escravos também podiam organizar suas confrarias e participar de atividades religiosas. Os espaços de sociabilidade, sob a vista da Igreja, também funcionavam como lugares de troca e mesmo de discussão por parte dos leigos. A evangelização não se encerrava apenas nos recintos das igrejas, parecia estar presente no cotidiano colonial... As confrarias eram organizações nas quais os leigos buscavam não só a participação na vida clerical, como também a conquista de alguns benefícios. (p 142)

A informação de que, no Brasil, tanto as irmandades como as ordens terceiras emergiam, organizavam-se e mobilizavam-se em função da promoção do culto a um santo nos parece uma pista considerável no que concerne ao entendimento da irmandade da Água Branca. Além do mais, considerando-se que, segundo alguns estudos históricos, como Martins e Oliveira (2009) uma porção destas instituições era fundada objetivando a construção de oratórios, de ermidas e de capelas, seria lógico concluir de certa tradição histórica, por certa prática contumaz característica da religiosidade brasileira. Mormente porque algumas destas entidades eram consagradas à mesma figura de São José e isto, considerando desde, pelo menos, dois séculos antes da chegada dos imigrantes poloneses ao hoje município de São Mateus do Sul. O estudo realizado por Daniel Precioso (2009) a respeito deste tema ilustra o que seria a plataforma para uma leitura linear. Segundo o autor,

A Confraria de S. José dos Bem Casados dos Homens Pardos de Vila Rica foi erigida em meados da década de 1720 na Paróquia de Antônio Dias, sendo transferida, posteriormente, para a de Nossa Senhora do Pilar provavelmente em virtude da doação de um lote de terras no morro de São Sebastião feita pelo Senado da Câmara. Em 1726, os devotos do Gloriozo Patriarcha receberam uma provisão para construção de uma capela própria, erguida à base de madeira, doada também pela Câmara. (2008, p. 1)

A doação do lote de terras, por parte do senado da Câmara, em Vila Rica, situado no morro de São Sebastião - década de 1720, Brasil colonial - poderia ser pinçada como argumento/evidência de precedentes históricos seculares para a interpretação do acontecimento referente à colônia Água Branca. Parece que, em ambos os casos, os devotos de São José, dito glorioso patriarca, recebem alguma espécie de suporte para a construção de edifícios com a finalidade precípua da prática do culto religioso. $\mathrm{O}$ apoio, nesses casos, seria na forma de áreas de terras.

Por um lado, o santo da Água Branca - São Mateus/PR - pode representar um contraponto ao São José dos Homens Pardos da Vila Rica, pois os imigrantes poloneses aparecem, pelo menos em alguns textos da historiografia regional, como uma espécie de 
blindagem a uma possível africanização do Brasil. ${ }^{5}$ É bem demarcado o teor de alguns estudos tais como o realizado por Carvalho (2011), investigação a respeito do chamado movimento de constituição da identidade cultural paranaense. A autora escreveu que, no interior daquela mobilização, vários intelectuais 'paranistas' recorreram à “teoria do branqueamento que, baseada no darwinismo, pretendia 'clarear' a população do estado através da nova imigração, buscando criar uma identidade paranaense com a imagem do imigrante ideal (loiro, de olhos azuis).” (CARVALHO, 2011, p. 21).

Por outro lado, a irmandade de São José vincula a imigração polonesa no Paraná do século XIX à história dos 'mestiços' mineiros do século XVIII. Tal vínculo se dá por meio da figura do santo, por intermédio da cultura religiosa das irmandades embora a cultura eslava, ${ }^{6}$ a princípio, não seja caracterizada por este tipo de associação.

No âmbito da história da imigração européia para o Brasil, a constituição de associações religiosas devotadas ao nome de um santo padroeiro, de fato, não se restringe ao catolicismo romano. Conforme Bakour (2007, p.42),

a Igreja Ortodoxa chega ao Brasil junto com imigrantes do leste europeu (russos, poloneses, gregos), e os árabes, fundando diversas paróquias ligadas aos Patriarcados e Arquidioceses aos quais eram submetidos em seus países de origem.

O autor ainda afirma que:

Em 1897, membros da comunidade ortodoxa antioquina fundaram a primeira sede da Sociedade Ortodoxa São Nicolau em uma sala comercial à Rua Buenos Aires, na Cidade do Rio de Janeiro, onde promoviam reuniões para discutir as necessidades culturais e religiosas do grupo e promoviam encontros recreativos para a comunidade. (BAKOUR, 2007, p. 43)

Diferentemente da irmandade de São José da Água Branca, a sociedade católica ortodoxa dos imigrantes árabes é, caracteristicamente, uma confraria localizada numa região urbana. O terreno em que foi construído o prédio para sediá-la, juntamente com o edifício construído para o funcionamento da igreja, (localizado na Rua Gomes Freire centro da cidade) foi adquirido “... com os fundos arrecadados pela Igreja e doações da comunidade." (BAKOUR, 2007, p 43).

A fundação dessas sociedades estabelecidas no âmbito da imigração do final do século XIX e a relação com a doação e a aquisição de terrenos para a construção de templos religiosos podem estar vinculadas às mudanças políticas ocorridas no Brasil. Neste período, o regime monárquico era substituído pelo republicano. Tanto a irmandade de São José (os imigrantes poloneses) quanto a de São Nicolau (dos 
imigrantes árabes) podem ser situadas na assim denominada segunda fase da política de imigração e colonização brasileira. De acordo com Iotti (2010),

Em relação ao período republicano (1889-1914), a política de imigração e colonização adotada pelo governo federal pode ser dividida em três fases distintas. A primeira, de 1889 a 1891, quando a recém instalada República deu continuidade a política imperial, mantendo algumas concessões para o transporte e instalação de imigrantes. A segunda, de 1891 a 1907, quando o poder público transferiu para os estados a tutela dos negócios ligados à imigração e à colonização. A terceira, de 1907 a 1914, quando a União voltou a intervir no processo de atrair imigrantes e de criação de núcleos coloniais, promulgando uma série de medidas, 'já que a maioria dos estados não podia fazê-lo, ou por falta de meios ou por ausência de uma infra-estrutura (sic.) que os pudesse apoiar nestes serviços'. (s/p)

A Colônia de Água Branca, fundada no ano de 1891 - ano de transição entre a fase em que o governo federal transferiu para as unidades da federação a responsabilidade sobre a imigração/colonização e o período em que apenas se deu continuidade à política imperial - é a que nos interessa aqui, entre outras coisas, por tratar-se e um período de transição.

A política de imigração brasileira exercida durante o regime imperial pode ser, resumidamente, assim definida. Por um lado, nota-se certa tendência de continuidade em relação à estratégia adotada por D. João VI que consistia em fomentar " $a$ entrada de imigrantes destinados a núcleos de pequena propriedade, com a finalidade de colonizar" (IOTTI, 2012, s/p). Por outro lado, a autora assinala que houve a disposição de promover a entrada de mão de obra assalariada que viesse a substituir a regime de trabalho escravo.

No período que se estende entre a proclamação da independência do Brasil (1822) até o ano de 1830, o Imperador assumiu, pessoalmente, o poder de decidir e legislar a respeito da criação de novas colônias e a prerrogativa de dirigir os parâmetros políticos do ingresso de imigrantes europeus no território de domínio imperial. Praticouse, nesta época, a política de criação de núcleos coloniais, utilizando-se a concepção de cidade renascentista como modelo de assentamento humano.

Pressupomos que o conhecimento referente a esse aspecto singular da política de imigração adotada no Brasil imperial nos auxiliará a compreender melhor a criação da irmandade da Água Branca, devido às implicações do padrão renascentista adotado. Como se fosse uma planta arquitetônica dos povoados, nesse modelo, os templos religiosos, juntamente com os edifícios do poder público, constituíam-se em referências 
básicas para a distribuição dos lotes. Essas edificações, como se pode comprovar por meio da observação de cidades originadas das colonizações planejadas e executada nessa época, ocupam o lugar central da área destinada à povoação.

No regime imperial as terras eram todas de posse do imperador. O monarca mesmo, geralmente, outorgava o terreno em que seriam construídas as dependências necessárias ao funcionamento de tais estabelecimentos. Note-se que, nessa fase, foi criada a colônia imperial de São Leopoldo, considerada como um dos marcos iniciais da colonização não lusa, desenvolvida na região sul do Brasil. Ressaltemos, também, que os encaminhamentos políticos no âmbito da imigração adotados por D. Pedro I provocaram reações adversas no parlamento. Tanto foi que, no ano de 1830, por meio da lei do Orçamento, suspendeu-se toda subvenção estatal à colonização estrangeira.

Conforme Iotti (2012), a abdicação do imperador causou o abandono da política de imigração subsidiada pelo poder central. Essa época de ausência administrativa tem como balizas os anos de 1831 e 1840, ou seja, o período da regência. Para alguns estudiosos do tema, tal ocasião representa a vitória do grupo constituído pelos latifundiários brasileiros que eram hostis à colonização estrangeira.

A autora aponta que o governo regencial intentou dividir com as províncias a tarefa do povoamento por meio da colonização. As tentativas, no entanto, não foram bem sucedidas, porque, entre outros fatores, estas unidades administrativas careciam de recursos financeiros para executar tais fins. Deste ponto de vista (de história política) o ano de 1841 representa uma data marcante na esfera da imigração: os parlamentares brasileiros reviram as questões de terras e da colonização. Tentaram montar uma estrutura administrativa capaz de oferecer o suporte necessário nessa área (IOTTI, 2010). Então nesse período, foi promulgado o regulamento que previa a concessão de terras devolutas às províncias para efeitos de colonização. ${ }^{7}$ Consideramos esta lei significativa para a compreensão deste tema em estudo. De fato, a lei $\mathrm{n}^{\circ} 514$ é considerada por alguns estudiosos do assunto como uma tentativa de se estabelecer a clara distinção entre certas categorias de colônias. Dividia-as em duas classes: as imperiais e as provinciais. A promulgação dessa regra, por força de lógica, representa o início do período marcado pela incerteza no tocante às competências do poder central e da administração local em relação aos assuntos da imigração.

Cabe notar que, esse conjunto de fatores implicou certa oportunidade para que os governos provinciais colocassem em pauta os interesses regionais. $\mathrm{O}$ atual estado do Paraná pertencia à província de São Paulo, unidade administrativa que demandava 
providências em relação à questão do povoamento e ao assunto das fronteiras. Concomitantemente, nesse período registra-se a entrada mais efetiva do setor da iniciativa privada nos negócios da colonização. ${ }^{8}$

Consideramos a Lei de Terras como um marco historiográfico crucial nos estudos que dizem respeito ao uso, à posse e à propriedade das terras no Brasil. Tal norma estabeleceu que o título de posse originado por meio da compra é o único legalmente válido em território nacional. Por consequência, essa lei, que foi regulamentada no ano de $1854,{ }^{9}$ apontava uma nova tendência na política migratória: a suspensão da antiga prática governamental da doação de lotes aos colonos e imigrantes para efeito de povoamento e colonização. Assinalava, igualmente, um sério obstáculo à política estatal de doação de terras com a finalidade da construção de templos em espaços de implantação de novos núcleos populacionais.

Na concepção de alguns estudiosos do assunto tais como Beatriz Maria Lazzari (1980), o estabelecimento de um valor financeiro para as terras representou uma estratégia da burguesia para aumentar o exército de mão de obra de reserva, o que implicou o surgimento das colônias de parceria. ${ }^{10}$

Numa época mais próxima à fundação da colônia Água Branca, houve o recrudescimento do fluxo migratório. Trata-se do período demarcado pelos anos de 1847 e 1889, em que foram promulgados diversos atos legislativos visando facilitar e estimular a imigração. A partir de 1884, período final do império, os cafeicultores começaram a atuar no sentido de atrair imigrantes para o estado de São Paulo, mais precisamente, para as regiões cafeeiras. Podemos dizer que a tendência, nesse caso, será da entrada da iniciativa privada nesse ramo o que não significa a extinção da prática das doações de terras para igrejas e santos. Concessões de terras de proprietários particulares para finalidades religiosas e filantrópicas merecem um estudo à parte.

A doação de terrenos para o santo padroeiro ou para alguma irmandade, assim como era costumeiro favorecer as condições para a prática da religião em novos assentamentos e onde quer que prosperasse um agrupamento de cristãos/súditos, parece prática bem antiga na história do Brasil. Inclusive remoto é o uso da doação de terras pelo poder público para a construção de templos. Trata-se de uma política antiga e extensa no tempo uma vez que se verifica, pelo menos, até os primeiros anos de instauração do regime republicano no país.

Classificamos como política de longa tradição porque, ainda no período colonial, o rei Pedro II de Portugal, ofereceu como donativo um terreno localizado na 
Bahia à Irmandade Nossa Senhora do Rosário dos Pretos. A finalidade era a construção de um templo. Amorin, Andrade, Cardona e Umbelino (s/d) afirmam que essa:

Irmandade teve sua primeira sede no início de 1685 e funcionou na antiga Igreja da Sé ou Santa Sé Catedral da Bahia. Em 1696, recebeu um terreno para a construção da Igreja, como doação de D. Pedro II. Este terreno era o local onde existia um barracão, que servia para reuniões diárias de negros. (2012, s/p)..

A oblação do rei português nos permite relacionar, como exemplo de uma antiga tradição política, a região da Bahia - final do século XVII com o território do Paraná final do XVIII, os imigrantes poloneses e com negros trazidos da África ou nascidos no Brasil. A história da imigração de habitantes da Europa central para o Brasil, todavia, tem seu marco estabelecido em outro ato real. A figura/referência é a de Dom João VI, na “... Carta Régia de 02 de maio de 1818, autorizando o estabelecimento de algumas famílias suiças no Brasil." (IOTTI, 2012, s/p). Afirma-se que essa epístola "real"

Assinala o início da imigração planejada, escolhida e subsidiada pelo Estado. Segue-se a este documento, uma série de outros regulamentando o estabelecimento de imigrantes europeus em território brasileiro. Entre eles, o Decreto de 06 de maio de 1818 mandando comprar a fazenda do Morro Queimado, em Cantagalo, no Rio de Janeiro, para o assentamento de uma colônia de suíços. (IOTTI, 2012, s/p.).

Até então fora estimulada a vinda de europeus, mas tratava-se principalmente, de imigrantes açorianos. Estes, no entanto, eram súditos da corte portuguesa. $\mathrm{O}$ ato de dois de maio tornou-se referencial na perspectiva da historiografia brasileira da colonização e imigração, porque, entre outros motivos está o de que a colônia de suíços do Morro Queimado ${ }^{11}$ é a primeira considerada, propriamente, sob a categoria colonização de imigração.

Este assentamento tornou-se, então, significativo para a investigação do tema em tela por tratar-se de um evento que podemos submeter à mesma categoria sob a qual temos classificado o caso de Água Branca. Convém cotejá-los.

Pedro Machado de Miranda Malheiros (1819) fez um relato a respeito do deslocamento desses colonos suíços até o lugar de fixação das moradias a que foram destinados. A narrativa comporta elemento que nos remetem ao cuidado com o aspecto religioso implícito no episódio. Malheiros fez um relato organizando o tempo em relação momento da fala. Assim, afirma que,

Há também na Real Fazenda de Morro-Queimado uma Casa nobre, em cuja grande varanda há um oratório aonde se celebra missa, e pode servir a exercícios religiosos enquanto os colonos não edificam a igreja paroquial de S. João Baptista, e as duas capelas constantes dos Artigos 11 e 12 das mencionadas condições... (MALHEIROS, 1819, p 15). 
A questão do lugar do culto pode ser percebida em alguns desses assentamentos existentes na época do Brasil império. Veja-se, como ilustração, o caso talvez clássico, de Petrópolis, cidade considerada como a "segunda" ocupação urbana planejada do Brasil (a primeira, seria Sergipe, durante a dominação holandesa). No ano de 1843, foi editado o Decreto Imperial de $\mathrm{n}^{\circ} 155$, dispondo sobre a criação da colônia e alugando as terras ao major Júlio Frederico Köeler. Como previa o decreto “... o major... ao projetar Petrópolis, reservou um terreno para a construção de uma Igreja Católica..." (www.diocesepetropolis.org.br, 2012, s/p) É dito corrente que, também, foi reservado terreno para a construção de um Templo luterano.

A doação de lote para a edificação de templo católico poderia a ser efetivada, tranquilamente, porque as terras destinadas ao assentamento eram de propriedade da família imperial, confessamente católica. Nesse caso petropolitano, Dom Pedro I havia comprado a fazenda chamada Córrego Seco. Assim, afirma-se que "a catedral de São Pedro de Alcântara que teve sua pedra fundamental lança em 1876 teve, seu terreno doado pela princesa Isabel." (www.flickr.com, 2012, s/p).

A família real doava essas terras por serem propriedades particulares suas, uma vez que, nesse período, o poder do imperador no Brasil estava em declínio. Ele já não podia considerar-se como o titular absoluto das terras imperiais. Como diz Nelson Nozoe (2006, p.17),

As concessões de terras em sesmaria foram suspensas às vésperas da Independência até a convocação da Assembléia Geral Constituinte, em decorrência da multiplicação de abusos e escândalos, que configuravam situação de verdadeira calamidade. Entre a expedição dessa resolução e a aprovação da lei $\mathrm{n}^{\circ}$ 601, em 1850, ficou-se sem uma legislação referente às terras públicas.

Mas, além disso, podemos considerar que a código $n^{\circ}$ 601, a mencionada Lei de Terras, em certo sentido,

promoveu uma profunda mudança na concepção da propriedade da terra, que ao deixar de integrar o patrimônio pessoal do Imperador, que a distribuía segundo o prestígio social do beneficiário, passava a ser considerada tão-somente uma mercadoria, a ser adquirida na proporção do poder econômico de seu comprador. (NOZOE, 2006, p 18)

De qualquer maneira, em alguns casos, nesse tipo de assentamentos a que estamos nos referindo, também acontecia que o terreno para a construção da igreja fosse doado por algum benfeitor. Então, mesmo quando se tornou restrito e nulo o poder monárquico relativo à distribuição de terras, não cessou a prática de doação de lotes 
para construção de templos. Uma prática, por assim dizer, familiar entre os proprietários mesmo não pertencentes à família real; mas, além disso, nota-se que mesmo quando a responsabilidade pela colonização passou a ser da competência das províncias, perdurou o cuidado com o assunto "casa de orações ou de culto". Para exemplificar, recorremos à normatização específica da província do Rio Grande do Sul.

A orientação geral nesta unidade administrativa imperial fora alterada a partir do ano de 1854 , com a Lei $n^{\circ} 504$, pela qual a colonização se faria com base na venda das terras e sustentada na indenização para cobrir as despesas nos cinco anos subsequentes ao estabelecimento nas colônias, cabendo à Repartição Geral das Terras Públicas a delimitação das mesmas. Essa Lei Provincial n $301^{\circ}$ constitui-se na Carta de Colonização da Província de São Pedro do Rio Grande do Sul, a qual estabelecia os princípios básicos da colonização. Entre eles, estabelecia-se que:

Art. $1^{\circ}$ - A Colonização da Província será feita sobre a base de terras; para este fim fica o respectivo presidente autorizado a comprá-las nos lugares mais próprios quando neles não haja terras devolutas compreendidas na disposição do art. 16 da Lei Geral $n^{\circ}$ 514, de 28 de outubro de 1848; esta venda será feita pela forma e sob as condições seguintes:

Art. $2^{\circ}$ - O Presidente da Província empregará as quantias anualmente consignadas pela Assembléia Provincial na compra de terras usadas para a lavoura, as quais mandará medir, dividir e demarcar os lotes em cem mil braças quadradas para serem expostas à venda aos colonos, sendo o preço mínimo de cada lote $300 \$ 000$.

Art. $3^{\circ}$ - Na mediação e demarcação das colônias o Presidente da Província fará reservar as terras precisas para estradas, porto, igrejas, cemitérios e outras servidões públicas, cuja necessidade se reconhecer. (HERÉDIA, 2001, s/p)

A lei provincial gaucha previa, em continuidade às políticas d'antanho, a reserva de terras para Igrejas e cemitérios e outras servidões. É interessante notar que a prática religiosa classifica-se como servidão, um termo que no âmbito da cultura portuguesa da época pode ser traduzido como: espaço de utilidade pública. Não investigamos se a política de reservar lotes para a construção de templos foi adotada em outras províncias brasileiras no final do império, mas nota-se boa quantidade de referências relativas ao espaço religioso no assentamento de imigrantes.

Assim, parece ter sido um tanto frequente acontecer de os imigrantes assentados se mobilizarem para reivindicar providências junto aos governantes a respeito da doação de lotes para em função da religiosidade. Os imigrantes assentados no atual município de Alfredo Chaves, estado do Espírito Santo, mobilizaram-se, no dia quatro de janeiro de 1879. 
Nessa data, também foram entregues as casas e os títulos provisórios dos lotes aos colonos, e também foi solicitada pelos colonos a construção de uma igreja, um cemitério e uma escola. Em virtude da demora de atendimento pelo governo até meados daquele ano, os próprios colonos providenciaram essas construções. Primeiramente, a igreja e o cemitério foram construídos. Para a construção da capela, os colonos propuseram ao governo o reaproveitamento das madeiras dos barracões, em que inicialmente foram instalados. Como acabaram construindo-a por conta própria, utilizaram-se desse material. (www.hcomparada.ifcs.ufrj.br, 2012, s/p).

A solicitação e a atitude dos imigrantes assentados são compreensíveis porque o Ministério dos Negócios da Agricultura dos Negócios e das Obras Públicas houvera se comprometido, oficialmente, com a provisão de tais questões. O compromisso fora feito por meio do documento intitulado como Dados estatísticos e esclarecimento para os imigrantes. Trata-se de texto datado do ano de 1875, contendo informações estatísticas básicas a respeito da província do Paraná. Circulava na Europa em língua portuguesa, inglesa e alemã, pelo menos. Na parte que versava a respeito dos 'favores aos imigrantes', podia-se ler o seguinte:

Nas colônias há sempre obras ou execução á custa do Governo, taes como estradas, escolas, igrejas e capellas, etc, etc.; permitte-se aos colonos trabalhar nessas obras publicas a salário durante os três primeiros mezes... Em todas as Colônias o Governo Imperial mantém escolas de primeiras letras para meninos e meninas; padre do culto dos colonos; e se encarrega das principaes obras públicas, como caminhos de ferro, estradas de rodagem, abertura de canaes, melhoramento dos rios navegáveis, etc. (PARANÁ ,1875, p 111-112).

O documento/propaganda permite vislumbrar uma pretensa cotidianidade no âmbito do sistema de colonização brasileiro que parece não ter sido completamente abandonada na passagem do regime imperial para o republicano. Dependendo da província/estado, a reserva do espaço para construção do lugar do culto, era ainda feita por engenheiros paulistas no início do século XX.

Em 1905 o Governo do Estado reserva uma área de 20 alqueires na margem Direita do Rio Corumbataí, onde se encontrava a estação ferroviária, que seria destinada a futura povoação e a um centro industrial e comercial do núcleo; no mesmo ano o Governo envia o Engenheiro Tertuliano Gonçalves para levantar a planta do Núcleo colonial e Projetar a Planta da Futura Povoação... Em 1912 é concluída a Igreja Matriz de São José no terreno que lhe havia sido reservado por ocasião da criação do núcleo colonial. (www.corumbatai.sp.gov.br, 2012, s/p).

Tendo como base, ainda, o estado de São Paulo, o templo nem sempre era construído com recursos governamentais. O núcleo colonial Antônio Prado, Ribeirão 
Preto (SP), serve como ilustração.

Em 18 de outubro de 1892, os moradores se reuniram em um abaixo-assinado pedindo o lote 7A da Sede, juntamente com algum auxílio financeiro, para a construção de uma capela. Como o Núcleo ainda não havia sido emancipado nesta ocasião, o pedido foi feito ao Secretário de Estado dos Negócios da Agricultura, Jorge Tibiriçá, que negou o pedido, alegando que e Estado não podia conceder subvenções ou auxílios a nenhum culto, cujo exercício é inteiramente livre, sem dependências nem relações oficiais. Mesmo assim, os colonos se uniram na construção de uma capela menor, que foi a de Santo Antônio, na Segunda Seção, demolida na década de 1980, para dar lugar à Igreja São Pedro. (www.arquitetura.eesc.usp.br, 2012,s/p).

A posição do Secretário, que posteriormente viria a ser o governador paulista, era condizente à opinião de certos grupos de republicanos em relação à doação de terras em geral e, particularmente, à concessão de lotes para a edificação de templos. Podemos citar como evento ilustrativo de tal posicionamento a história da reconstrução da Basílica Menor de Curitiba, episódio que, a nosso ver, esboça esse momento de transição. No ano de

1877 - O francês Alphonse Conde des Plas projeta a catedral em estilo gótico. Começam as obras, mas no ano seguinte param por falta de verbas. 1880 - As obras são retomadas com recursos da loteria. A demolição da antiga Matriz é concluída. 1889 - A República é proclamada e os trabalhos param. Estado e Igreja se separam, não há mais compromisso estatal com a construção. 1893 Finalmente a obra da catedral foi dada como concluída. (www.gazetadopovo.com.br, 2012,s/p).

É certo que a proclamação da república no Brasil significou o fim do regime de padroado, assim como o episcopado brasileiro, liderado por D. Antônio de Macedo Costa havia vencido o embate contra o imperador D. Pedro II, não aceitando que membros da maçonaria fizessem parte de irmandades religiosas. Apesar destas questões, a separação entre Estado e Igreja no tocante à questão do serviço religioso em áreas de imigração e assentamento de colonos parece não ter sido tão afetada, pelo menos de imediato. Por um lado, a política imperial caracterizava-se como promotora desses serviços que muitas vezes não se efetivavam. Por outro, o governo republicano, promotor da laicização do Estado com a publicação do decreto $119-\mathrm{A},{ }^{12}$ em certa medida, seguiu a política imperial de imigração e assentamento por alguns anos. Podese perceber o estado laico doando terras para a construção de templos, inclusive no estado do Paraná.

Em se tratando da região das matas dos pinheirais, dos campos gerais e dos de Guarapuava, existem narrativas "oficiais" dando conta de que vários terrenos para construção de lugares de culto são provenientes de doações feitas por particulares. Aliás, era uma prática bastante antiga e, até certo ponto comum, nessas regiões, que um 
proprietário devoto de determinado santo doasse-lhe parcela de suas terras. Assim, ocorreu com a catedral de Ponta Grossa,

A parte destas terras que correspondia ao local escolhido para a ereção da Capela de Sant'Ana, fora comprado por Miguel Ferreira da Rocha Carvalhais, dono da fazenda Bom Sucesso e de toda a invernada da Boa Vista, e que doou o lugar para a construção do pequeno templo religioso. (www.diocesepontagrossa.com.br, 20120, s/p).

A respeito das terras em que se edificou a catedral de Guarapuava existe narrativa semelhante. Afirma-se que

No dia 08 de dezembro de 1771 foi rezada a $1^{\text {a }}$ missa nos campos de Guarapuava... A primeira capela, onde o povo começou a se reunir para rezar fora das fazendas, foi em Santana, por volta de1810... Em 1882, foi erguida no Passo da Reserva a primeira Capela com a devoção a Nossa Senhora da Conceição Aparecida... O início da construção da primeira Igreja na 'Vila Nova' foi em 1923, sendo o terreno doado por João Ferreira da Silva... (www.catedralguarapuava.webnode.com.br, $2012, \mathrm{~s} / \mathrm{p})$.

Parece que Santana era devoção muito popular nestas terras de campos e descampados do Paraná do século XVIII e XIX, mas as narrativas de doação de terras são mais generalizáveis ainda. O caso da Igreja Matriz de Palmeira-PR é emblemático, uma vez que a Colônia Água Branca, como veremos adiante, foi implantada no território que, antes da criação de São João do Triunfo, pertencia ao município de Palmeira. Conforme matéria publicada em 31 de maio de 2012 - imprensa local,

No dia sete de abril de 1819, o tenente Manoel José de Araújo entregou ao padre Antonio Duarte dos Passos, o documento no qual doava uma extensa área de terras à Nossa Senhora da Conceição para a construção da nova matriz. Quase duzentos anos depois, após uma ação de Usucapião que durou cinco anos, finalmente o prédio da igreja matriz de Palmeira é, de fato e de direito, propriedade da Igreja Católica. É que, durante todos esses anos, a Igreja teve a propriedade do imóvel baseada somente naquele documento de posse. Segundo o advogado Carlos Eduardo Mezzadri, que defendeu a Mitra nesta ação, não havia nenhum título de propriedade. No ano de 2007, foi dado entrada na Justiça com uma ação de reconhecimento do Usucapião que, no último mês de maio, teve, finalmente, um final feliz com a determinação judicial que outorga a propriedade daquela imóvel à Arquidiocese de Curitiba.O advogado lembra que, de acordo com o documento original, a doação feita pelo tenente Manoel Araújo foi de uma extensa área de terras... (www.tvondalivre.com, 2012, s/p)

Como se vê, a questão das terras de Nossa Senhora da Conceição (valeria uma pesquisa a respeito de terras de santo no Paraná) inicia no período colonial, atravessa 
todo o período do Brasil Império, adentra à República até a contemporaneidade.

O caso da catedral de União da Vitória, também, pode ser considerado como singularidade, por conta de que, o terreno para construção deste lugar de culto foi doado pelo governante estadual, em pleno regime republicano que extinguira o padroado. Conforme o site da catedral,

A pedra inaugural da Igreja Sagrado Coração de Jesus, atualmente Catedral de União da Vitória, foi benta pelo Bispo de Curitiba, Dom João Francisco Braga,em 20 de maio de 1917, e construída primeiramente com verbas do Estado Paranaense, e em seguida, do povo local. O terreno da atual Catedral foi doado pelo Governador do Estado do Paraná Dr. Affonso Alves de Camargo. (www. catedraluniao.com. br, 2012, s/p).

Note-se que Affonso Alves de Camargo ${ }^{13}$ era republicano e ligado ao ideário positivista, ${ }^{14}$ portanto, pelo menos em tese, contrário ao fornecimento de subsídio por parte do Estado à Igreja católica. Mas a concessão desse terreno, especificamente, pode ser explicada com base na legislação brasileira posterior a 1850. Girolamo Domenico Treccani (s/d) escreveu que

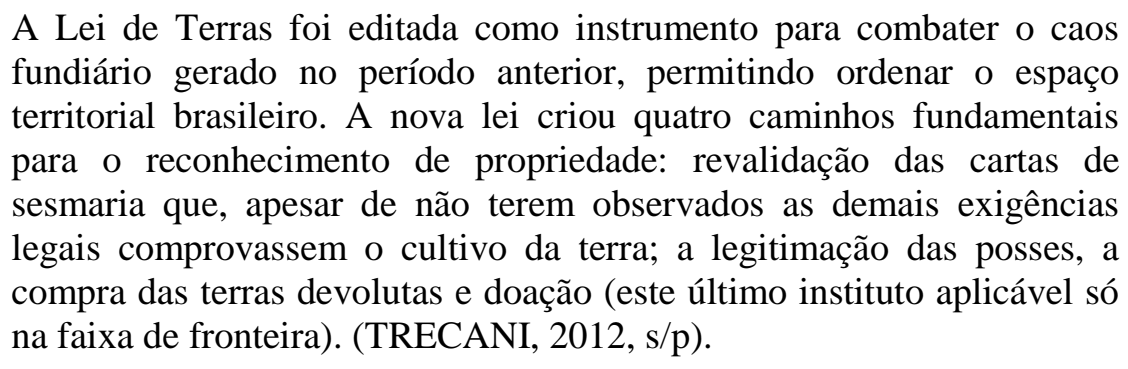

Pode ser que tenha sido aplicada a prerrogativa da faixa de fronteira, pois União da Vitória localiza-se numa região outrora disputada pelo Brasil e pela Argentina (no final do século XIX); mas a chamada questão de Palmas fora já solucionada, no ano de $1895,{ }^{15}$ ao passo que Affonso Alves de Camargo tornou-se governador no ano de 1916, ou seja, vinte e um anos depois.

$\mathrm{O}$ ano da posse do governador Camargo, no entanto, coincide como a data em que findou a Guerra do Contestado. Foi um conflito envolvendo, entre outros aspectos, exatamente a definição das fronteiras entre o estado do Paraná e o de Santa Catarina. A terra doada pelo governador, portanto, não se localizava numa área de fronteiras internacionais, porém será bem plausível pensar que se consideraram as fronteiras internas para efeitos de legalidade da tal doação.

A região em que hoje se localiza o município de União da Vitória foi espaço da disputa entre os dois estados e, nessa faixa de fronteiras internas foram instaladas várias 
colônias de imigrantes, principalmente, poloneses e ucranianos (também chamados rutenos). Podemos dizer, em acordo com o Francisco Gutierrez Beltrão (Paraná, 1907), que a ocupação dessa região fronteiriça iniciou no final da década de 1870. Em 14 de janeiro de 1908, o então secretário de Estado dos Negócios Públicos Obras e Colonização, engenheiro Francisco Beltrão, em documento dirigido ao então vicepresidente do Estado, o coronel Joaquim Monteiro de Carvalho e Silva relatou o seguinte:

Em 1876 foram escolhidas terras à margem do rio Iguassú para fundação da colônia Kittoland, estendendo-se essa escolha até a actual colônia S. Matheus, no município de São João do Triumpho; caducando o contracto para isto feito com Charles William Kitto. Só em 1890 foram iniciados pelo governo os serviços de localização de imigrantes nas fertilíssimas terras deste município... (PARANÁ, 1907, p 56).

Beltrão afirma, em seu relatório, que a colônia São Mateus fora fundada no ano de 1890 com a denominação de 'Maria Augusta' e que estava situada à margem direita do rio Iguaçu, em terras adquiridas pelo governo. Informava, igualmente, que a aquisição se dera no ano de $1876^{16}$ e que a sede da colônia localizava-se há trinta e três quilômetros do município de São João do Triunfo.

O dado mais valioso para essa nossa discussão, no entanto, consiste em que os terrenos para o estabelecimento da colônia São Mateus foram adquiridos pelo governo, em 1876, e que, por conseguinte, estávamos sob o regime imperial. Beltrão agrega a informação de que a obtenção dos ditos terrenos se deu por meio de troca, ou a troco de terras devolutas existentes no município da Lapa, escambo de terras, o que renderá bom campo de investigação.

Conforme as narrativas do agrimensor Sebastião Edmundo Wos Saporski (apelidado Eti) pressupomos que a troca de terras entre particulares e as instâncias governamentais era prática, até certo ponto, corriqueira na região. Assim,

No dia seguinte, o comissário, levando consigo Eti, seguiu de canoa para fazer uma visita a um certo José Fortes, que era proprietário das terras situadas em frente dos terrenos de Bueno e de Braga. Nas proximidades da foz do rio Taquaral, no porto de Humaitá... Fortes tinha sido a seu tempo proprietário de extensos terrenos entre os rios Iguaçu e Negro. Mas posteriormente efetuou uma transação de troca com o governo, recebendo os terrenos de São Mateus. Essa colônia dava de frente para o rio Taquaral e para o Arroio Emboque. ${ }^{17}$ (SAPORSKI, 1972). 
O agrimensor refere-se à propriedade de Bueno e de Braga que pode ter sido medida em vista do assentamento de colonos poloneses. Afirma, ainda, que,

O comerciante Bueno, juntamente com um outro cidadão da Lapa chamado Braga, possuíam terras às margens do Iguaçu, ente os rios Água Branca e Taquaral, afluentes do Iguaçu. Foi para a medição dessas terras que veio o comissário de terras. Eram grandes extensões de terras desabitadas, sem nenhuma construção, se não se contassem algumas barracas para os caçadores que aí vinham caçar, pois havia caça à vontade. De vez em quando também os selvagens Botocudos visitavam essas regiões, em busca de caça... Seguiram todos juntos até a foz do Água Branca, de onde foram iniciadas as medições. (MEMÓRIAS, 1972, s/p).

O ‘engenheiro Beltrão’ escreveu que a colônia Água Branca, fora “... fundada em 1891 entre a Villa de São João do Triumpho, da qual dista 24 kilômetros, e a colônia São Matheus, foram ahi localisados immigrantes polacos; constituída de 137 lotes..." (Paraná, 1907, p.75).

Para se ter uma idéia da dimensão destas colônias basta dizer que a de São Mateus foi dividida em 245 lotes rurais e 78 urbanos. As colônias de Água Branca, Eufrosina e Rio Claro, todas fundadas no ano de 1891, foram divididas em 137, 375 e 1371 lotes respectivamente. ${ }^{18}$ Mas além da divisão em lotes, havia uma classificação 'administrativa' das colônias.

Tal 'fracionamento' fora estabelecido, em 28 de julho de 1904, pelo secretário de Estado dos Negócios de Obras Públicas e Colonização, Joaquim P. P. Chichorro Junior, secretário que antecedera o 'engenheiro Beltrão'. Na gestão daquele secretário organizara-se um regulamento dispondo a respeito da cobrança da dívida dos assentados ao Estado. Pela nova norma, repartira-se a área colonizada as margens do Iguaçu em vinte partes contendo, cada uma delas, de uma a quatro circunscrições, ou seja, divisões menores. Rio Claro, considerado como o mais extenso domínio de 'imigrantes eslavos' à época, foi dividido em quatro circunscrições. A quarta circunscrição compreendia as colônias de número 4, 5 e 6. A história dessa divisão nos interessa porque, conforme o relatório de Beltrão, a Colônia Cinco, desde 1897, já contava com um templo religioso, a primeira Igreja Ucraíno Católica do Brasil; mas, e a Água Branca?

Os termos desta divisão das colônias indicam que esta, juntamente com a de Taquaral, tornou-se parte da segunda circunscrição da colônia São Mateus. ${ }^{19}$ Fica claro, então, que a construção da capela de São José da Água Branca localizava-se numa das circunscrições da colônia acima mencionada, mas emergem as questões referentes à 
aquisição das terras e à dinâmica organizacional dos imigrantes em vista do lugar da prática religiosa coletiva.

A forma de organização dos fiéis para a construção do primeiro templo, neste caso, deve ter sido à adotada nas diversas colônias da região. Embora os fiéis congregados à capela de São José seguissem ou adotassem o rito latino, tal processo pode ser ilustrado por meio do depoimento de Ivan Pacevich, imigrante ucraniano instalado na colônia Rio Claro, no ano de 1891. Ele seguia o rito ucraniano e, referindose à colônia em que habitava, declarou o seguinte:

Igreja, no começo nós não tínhamos nenhuma. O Natal e a Páscoa nós comemorávamos em casa... Só em 1897, com a vinda do Padre Rosdolskyi, na Colônia 5 foi construída a primeira Igreja. Duas ou três vezes ao ano nós íamos a pé pelas picadas até à Igreja na Colônia Cinco... (CZAIKOWSKI, 2010, s/p)

A dinâmica de construção da Igreja da Colônia Cinco pode ser considerada, a princípio, como modelo do que ocorria nessa região de imigração 'eslava' no sul do Brasil, neste período; mas podemos destacar algumas diferenças. Os imigrantes ucranianos, por exemplo, ao que parece, receberam assistência religiosa mais cedo do que os poloneses. (Babbar, 2008, p 37) Conforme os textos escritos por Valdomiro Haneiko, a respeito do Padre Nicon.

O jovem sacerdote... Veio para a Colônia Rio Claro, iniciando uma nova página na história da imigração ucraína no Brasil. Estabeleceu-se na Colônia 5, na residência de Teodoro Potoskei... Já no início de 1897, convocada uma reunião de todos os lavradores da região, que compreendia 6 colônias, além dos vicinais, foi planejada e decidida a construção de uma igreja, uma moradia para o sacerdote e de duas salas: uma para reuniões e outra para a biblioteca. Foi escolhida então a Colônia 5 como o ponto central da região e onde deveria ser edificada a igreja e residência sacerdotal. Para se obter verba suficiente para a obra, foi estabelecido que as famílias da quarta, quinta e sexta colônia colaborariam com 20 mil réis; os da terceira, segunda e primeira com 10 mil réis. (HANEIKO, 1985, s/p).

As seis colônias mencionadas no texto de Haneiko constituem as subdivisões principais da colônia Rio Claro. ${ }^{20}$ Podemos considerar, pelo depoimento, que esta deve ter sido a prática organizacional genérica dos fiéis em relação ao estabelecimento dos lugares de culto e oração, nas regiões de assentamento de imigrantes ucranianos no Brasil deste período; mas o imigrante polonês, nos parece que, não teve a necessidade de recorrer a tal expediente; teriam recebido benefícios governamentais nesse sentido? Pode ter ocorrido, aí, algum tipo de simpatia em relação ao rito latino. Note-se, em favor disso, que os ucranianos católicos da Colônia Rio Claro foram desligados do 
curato de rito latino, sediado em São João do Triunfo, por meio de Provisão datada de 28 de dezembro de 1906.

Cabe mencionar que conforme estas narrativas tão comuns ao meio, o lote em que foi construída essa igreja matriz de São João do Triunfo também fora doado por um proprietário de terras. Afirma-se que era João Nunes de Souza, tido como fundador da cidade. (www.infosaojoaobatista.blogspot.com.br , 2012,s/p). Antigo morador de São José dos Pinhais, teria se estabelecido no lugar de nome Rio da Vargem, mais tarde São João.

Com ele foi toda a família. Desbravaram a região... Abriram picadas na mata e fizeram propaganda para atrair outras pessoas. Uma comunidade foi gradativamente se formando... O povo do lugar construiu uma capela, na qual foi colocada a imagem de São João Batista. Muitas casas foram sendo construídas ao redor da pequena igreja. (www.cmsaojoaodotriunfo.pr.gov.br, 2012, s/p)

A forma da construção da capela de São João parece seguir os moldes das narrativas de povoamento efetuado por colonos nacionais, nesse caso, de modo mais ou menos espontâneo, por meio da ocupação e posse, legalizada posteriormente à fixação do núcleo habitacional. Faz sentido, também, a narrativa de que o padroeiro da primeira ermida fosse homônimo do doador do lote e organizador das tarefas de construção do estabelecimento que se tornou sede do curato, isto é, unidade administrativa desmembrada da paróquia de Palmeira. O desmembramento se deu com a nomeação de um pároco para atender os fiéis e dar assistência às unidades menores que passaram a ser, doravante, de sua jurisdição. Era o ano de 1900. (www.infosaojoaobatista.blogspot.com.br, 2012, s/p)

Nesse período, Água Branca era uma das unidades da recém-criada paróquia de São João. Isso fica evidente no relato de alguns missionários que, em fevereiro de 1904, forma designados para realizar o sacramento da crisma naquela região e estiveram empenhados em “... pregar missões, erguendo um grande cruzeiro na praça... as missões... aconteceram nas capelas de Rio Baio, Rio Bituva, Poço Bonito, Baitacos, Conceição, Água Branca, São Mateus, Rio Azul, Rio Claro e Poço Preto”. (www. infosaojoaobatista.blogspot.com.br, 2012, s/p)

Os padres missionários pertenciam ao rito latino e, como se nota, visitaram povoados em que funcionavam igrejas alinhadas ao rito ucraniano.

Evidencia-se, desta maneira, tratar-se de uma região culturalmente plural, em que coexistiam etnicidades e ritualidades distintas. Veja-se que os ucranianos católicos de Rio Claro, findadas as missões do rito latino, no prazo de dois anos, seriam 
desligados da paróquia de São João; mas, boa parte dos imigrantes assentados nessa colônia do Rio Claro era considerada como gente de etnicidade polonesa e, sendo católicos, praticavam o rito latino.

A percepção da diversidade religiosa, a perspectiva das cadências de organização comunitária e os modos de representar as etnicidades evidenciam-se numa correspondência enviada em 1897, ao jornal norte americano (Svoboda), por um imigrante ucraniano estabelecido em Rio Claro. Ivan Pacevich escreveu:

Temos aqui uma sala de leitura, junto à igreja e a residência que nós construímos para o nosso padre, Nikon Rozdolski. ...Quando nós aqui chegamos, encontramos apenas a floresta e morros. Agora a nossa colônia já se parece com um pequeno 'celó', com as propriedades instaladas dos dois lados da estrada principal. No centro da colônia, a nossa igreja, grande a majestosa... Os poloneses da Colônia Rio Claro, que ali se encontram já há sete anos, ainda não possuem a sua igreja, apenas uma capelinha. (www. infosaojoaobatista.blogspot.com.br, $2012, \mathrm{~s} / \mathrm{p})$

Podemos considerar, então, que havia uma ermida edificada pelos ou para os poloneses, portanto de rito latino, no Rio Claro de 1897. Consideramos, igualmente que a sede da igreja de São Mateus, também de rito latino, figura como ermida pertencente à matriz de São João de Triunfo. Estava no rol das comunidades visitadas pelos padres missionários, no ano de 1904.

Conforme o site dessa paróquia, a história começa com a vinda, para São Mateus do Sul, do padre polonês Ladislau Smolucha, em 1892. Uma pequena capela dedicada ao santo homônimo da colônia foi construída em 1895.

Em 1900 foi construída a Igreja de Nossa Senhora da Assunção, ao lado da atual Matriz São Mateus... Neste mesmo ano, no dia 21 de setembro (1908), aconteceu a emancipação política de São Mateus do Sul, desmembrado de São João do Triunfo. A capelania foi elevada à categoria de paróquia em 1926, tendo como primeiro Pároco o Padre Francisco Zdzieblo. No dia 16 de Junho de 1959 foi emitido um Decreto Episcopal, assinado por Dom Jerônimo Mazzarotto, Bispo Auxiliar de Curitiba, anexando a Paróquia São José, de Água Branca à Paróquia São Mateus. No decreto é pedido um zelo especial à comunidade da Água Branca, que ficou desprovida de padres... (www.psaomateus.com, 2012, s/p)

Água Branca, fora uma capela, assim como São Mateus, na época das missões de 1904. Depois de haver se tornado paróquia por algum tempo, voltava à condição capela, agora (1959) vinculada à paróquia de São Mateus. A história da constituição dessa sede paroquial é, por assim dizer, vinculada à tradição, à etnicidade e à cultura polonesa. Monika Gryczynska (s/d), por exemplo, relaciona tal história às figuras dos 
padres Smolucha e Zdzieblo. A escritora paranaense afirma que,

Em agosto de 1891, chegou à colônia o padre Ladislau Smolucha, que ocupou o cargo de pároco até 1916... Em 1896, foi fundada a Capelania de São Mateus, ligada à Diocese de Curitiba, por D. José de Camargo Barros, bispo de Curitiba. Depois das primeiras frustrações e desencantos, os colonos começaram a organizar-se... A construção da igreja polonesa em São Mateus foi uma das primeiras realizações da colônia. Seguiu-se a fundação da paróquia, em 1891, tendo o padre Franciszek Zdzieblo como pároco. Próximo à capela recém-construída foi edificada uma torre de madeira de dois pilares, onde se instalou o sino doado pelo comerciante Flizikowski. (www.monikagryczynska.files.wordpress.com, 2012, s/d)

A historiografia da imigração eslava fundamenta-se na tese de que, para esses povos, principalmente os poloneses, a presença de sacerdotes era fundamental nos assentamentos coloniais. Tal perspectiva era veiculada, por exemplo, na Gazeta Polska, que serviu de base para os estudos realizados por Lourival de Araujo Filho (2003). O autor afirma que havia certa movimentação dos colonos exigindo a presença de sacerdotes poloneses nas áreas de imigração e apresenta matéria veiculada na mencionada Gazeta ${ }^{21}$.

O povo polonês não admite sacerdotes brasileiros, cuja língua e ritos desconhece... Quem desconhece o rito e a língua evita a Igreja, que fala uma linguagem desconhecida. Tal a razão porque os poloneses não aceitam a 'fé brasileira'. A repulsa ao 'abrasileiramento' é um ato instintivo. (ARAUJO FILHO, 2003, p 50)

Textos desta natureza são, geralmente, considerados como evidências de certa pressão popular exercida pelos imigrantes visando o envio de padres para servi-los no âmbito da assistência religiosa. São, além disso, avaliados como indicativo de certa identidade cultural dos imigrantes poloneses, se presume, intensamente marcada pela religiosidade. Nessa mesma linha argumentativa, apresentam-se as narrativas a respeito de espaços de tradição tais como a da irmandade da Água Branca. Monika Gryczynska escreveu que, logo no início do povoamento,

Com a colaboração dos colonos... Foi construída uma capela no alto da colina. Logo abaixo foi cercado o terreno para o cemitério. Em 1900, o governador do Paraná, Francisco Xavier da Silva, passou a posse definitiva para a Irmandade de São José de um terreno de 214.000 metros quadrados, lugar onde já tinham sido construídos a igreja, a escola, o cemitério e a casa paroquial. Em quatro de setembro de 1891, chegou o padre Ludovico Przytarski, que foi designado pelo bispo da diocese de Curitiba, para atender aos habitantes de Água Branca. (www. monikagryczynska.files.wordpress.com, 2012, s/d) 
Para concluir podemos dizer que a instituição dessa irmandade representa um acontecimento singular no âmbito da história dessa região de imigração dita eslava. Pode ser compreendida como forma de organização desses imigrantes visando alguma forma de preservação do patrimônio pertencente à comunidade e de sua etnicidade. $\mathrm{O}$ 'patrimônio', conforme o estatuto, datado de 1941, trata-se de bens materiais e imateriais, sendo que os primeiros configuram-se como a própria capela e seu respectivo lote, o cemitério e, posteriormente, a escola que fora construída para atender os filhos dos colonos. O mesmo estatuto determina ao vigário da paróquia, uma série de funções dentre as quais: aprovar ou reprovar as ações da irmandade segundo as leis canônicas, remeter novas orientações, nomeação de comissões para estudos que atendam aos interesses da irmandade ${ }^{22}$ e, de forma mais explicita, no artigo 22.

Compete ainda ao Rev. Pe. Vigário, estimular a irmandade ao fiel cumprimento dos estatutos e das disposições da Igreja neste sentido, aconselhar os bons que se alistem na irmandade e velem pela boa administração dos seus bens. (ESTATUTO, 1941, s/p)

A irmandade de São José da Água Branca representa muito mais do que uma entidade criada para cumprir os fins estatutários que a regem. Na perspectiva da história cultural e da região, nos permite transitar pelos meandros da história do uso e da posse da terra no Brasil, tanto no âmbito da propriedade em geral quanto das terras pertencentes ou doadas a entidades religiosas. Podemos perceber o quão arraigadas em nossa história estão as relações entre confrarias, povoamento, lugares de culto, etnias, etnicidades e regionalidades. Vinculamos a Irmandade de São José da Água Branca ao assentamento de colonos brancos vindos da Europa central no final do século XIX e início do XX, à Confraria de S. José dos Bem Casados dos Homens Pardos de Vila Rica, no século XVIII, e à Irmandade Nossa Senhora do Rosário dos Pretos, da Bahia do século XVII, portanto, à colonização e à história das conquistas e da afirmação da liberdade dos africanos escravizados e dos afrodescendentes. São José da Água Branca é um desses eventos condensados, pois se situa numa região densa da história, conectando aspectos da vida cultural, religiosa e política do país. Está vinculada à etnicidade, ao povoamento, aos rituais, à organização dos homens e mulheres do campo e da cidade, por fim, à história da ruralidade brasileira.

\section{LAND AND DONATIONS - ChURChes, BRotherhood AND POLISH IMMigRants in PARANá}


ABSTRACT: questions concerning to the use and ownership of land are discussed in this research focusing on certain donations made by the State or by private owners for building temples and other religious destinations. The starting point is the Brotherhood of São José da Água da Branca, São Mateus do Sul, Paraná, established in a colony of Poles basically. Its intended purpose, among others, was to be responsible for 'ecclesial space'. Because it is a thematic focus, we make a way since colonial Brazil until the mid-twentieth century. We are referring also to other Brazilian states, although the focus is on the central southern state of Paraná. We can conclude, through this research, that this fellowship is located in a dense region of history, connecting aspects of cultural, religious and political life of the country. Is linked to ethnicity, to the occupation of space, to the rituals, to the organization of men and women from the countryside and the city, and finally, to the Brazilian rurality.

KEYWORDS: Colonization - Polish immigration - brotherhoods - dense region.

\section{NOTAS}

1 Artigo produzido com base no trabalho de conclusão de curso de História, UNICENTRO, Campus de Irati, ano de 2012, A irmandade Polônica de São José da Água Branca, da aluna Lediane Ferraz Chul, sob a orientação do professor José Adilçon Campigoto. Também teve por base, as discussões realizadas no âmbito do Laboratório dos Povos Eslavos e Faxinalenses, nesta mesma universidade, o que resultou na elaboração deste escrito. Além de participar da elaboração do texto, mencionada aluna colaborou com as entrevistas e parte da documentação, mormente, as cópias do estatuto da irmandade em questão.

${ }^{2}$ Este município localiza-se no vale do rio Iguaçu, há cento e quarenta e quatro quilômetros de Curitiba e foi desmembrado de São João do Triunfo, no ano de 1908. Água Branca é uma de suas localidades, distando cerca de quatorze quilômetros do centro da cidade. A lei estadual $n^{\circ} 763$, de 2 de abril de 1908, criava o município de São Mateus, que passou a denominar-se São Mateus do Sul pelo Decreto lei estadual no 199 , de 30 de dezembro de 1943.

${ }^{3}$ Sobre essa questão ver BOSCHILIA, R. O cotidiano de Curitiba durante a II Guerra Mundial. Boletim Informativo da Casa Romário Martins. Curitiba: Fundação Cultural, 
1995. GLUCHOWSKI, K. Os poloneses no Brasil. Porto Alegre: Rodzicz \& Ordakowski editores, 2005. WACHOWCIZ, R. C. As escolas da colonização polonesa no Brasil. In Anais da Comunidade Brasileiro-Polonesa. Curitiba: op. cit. vol. VII, 1970. NIKODEM, P. (1970). Saporski - o "Pioneiro dos Semeadores". In Anais da Comunidade BrasileiroPolonesa. Curitiba: op. cit. vol. I, 1970. O termo discurso é aqui utilizado no sentido de saber historiográfico.

4 Ver BLOCH, Marc. A Sociedade Feudal. Edições 70. BASCHET, Jérôme. A Civilização Feudal: Do Ano Mil À Colonização da América. Globo Editora. DUBY, Georges. As Três Ordens. Estampa. GOFF, Jacques. A Civilização do Ocidente Medieval. Edusc. D'HAUCOURT, Genevieve. A Vida na Idade Média. Martins Fontes. FRANCO JR, Hilario. A Idade Média: Nascimento do Ocidente. Brasiliense. ANTUNTES, Ricardo. O caracol e sua concha: ensaios sobre a nova morfologia do trabalho. São Paulo: Boitempo, 2005. GORZ. André. (org.) Divisão social do trabalho e modo de produção capitalista. Porto: Publicações Escorpião, 1976. HOBSBAWM, Eric J. Mundos do trabalho: novos estudos sobre história operária. 5. Ed. Rio de Janeiro: Paz e Terra, 2008. HOBSBAWM, Eric J. Os trabalhadores: estudos sobre a história do operariado. 2. Ed. Rio de Janeiro: Paz e Terra, 2000. HUBERMAN, Leo. A história da riqueza do homem. 21. Ed. Rio de Janeiro: LTC. MARX, Karl. Da manufatura à fábrica automática. In:. SPINK, M. J. P. (org.). A cidadania em construção: uma reflexão transdisciplinar. São Paulo: Cortez, 1994.

5 Ver AZEVEDO, Célia M. Martinho de. Onda Negra Medo Branco: o negro no imaginário das elites - Século XIX. Rio de Janeiro: Paz e Terra, 1987. ANDREAZZA, M. L.; NADALIN, S. O. Imigração e sociedade. Curitiba: UFPR, Departamento de História, 1993. LAMB, Roberto Edgar. Uma jornada civilizadora: imigração, conflito social e segurança pública na província do Paraná - 1867 a 1882. Curitiba: Aos Quatro Ventos, 1999.

${ }^{6}$ Chamaremos de cultura eslava, didaticamente, às manifestações culturais tidas como características dos chamados poloneses, ucranianos e russos.

${ }^{7}$ Lei n. ${ }^{\circ} 514$, de 28 de outubro de 1848.

${ }^{8}$ Dois fatores importantes são caracterizados como decisivos nesse aspecto: a Lei n. ${ }^{\circ}$ 581 , de 4 de setembro de 1850, proibindo o tráfico e a entrada de escravos no território brasileiro e a Lei de Terras, promulgada nesse mesmo mês e ano, que criou a Repartição Geral das Terras Públicas. 
${ }^{9}$ Lei regulamentada através do Decreto $\mathrm{n}^{\circ} 1318$ de 30 de janeiro.

${ }^{10}$ Como escreveu, também, Iotti: os cafeicultores recebiam empréstimos do governo imperial, em média dez contos de réis, que devolveriam em seis anos sem juros. Com esse dinheiro, contratavam empresas para aliciarem e transportarem imigrantes europeus. O pioneiro nesse tipo de iniciativa foi o senador Nicolau de Campos Vergueiro, que, em 1847, introduziu, na sua fazenda paulista de Ibicaba, 80 famílias vindas da Alemanha.

${ }^{11}$ Desta colônia se originou a vila de Nova Friburgo, criada oficialmente pelo Alvará de 03 de janeiro de 1820 .

${ }^{12}$ Decreto dede 07 de janeiro de 1890, que extingui o regime de padroado no Brasil.

${ }^{13}$ Affonso Alves de Camargo nasceu em Guarapuava a 25 de setembro de 1873. Filho de Pedro Alves da Rocha Loures e Francisca de Camargo, mudou-se para Curitiba ainda jovem, onde foi promotor público e professor catedrático da Faculdade de Direito da Universidade Federal do Paraná. Entrou para a política e elegeu-se deputado estadual diversas vezes, permanecendo no cargo de 1896 a 1907. Chegou a vice-presidente (1908 - 1912) e depois presidente de estado do Paraná (1916 -1920), como se chamava o título do governo estadual na época. Após o governo entrou para o Congresso Nacional, primeiro como deputado federal (1921 - 1922) e depois como senador (1922 - 1928). Retornou ao Paraná para governar o estado mais uma vez, de 1928 a 1930. Ainda no cargo de vice-presidente do Estado do Paraná atuou como advogado da Brazil Railway, no conflito de terras durante a Guerra do Contestado, obtendo a vitória judicial da ferrovia contra os detentores tradicionais das terras na região.

${ }^{14}$ Afonso Alves de Camargo era maçom e pertencia à Loja Luz Invisível no 0.749 Curitiba.

http://www.museumaconicoparanaense.com/Governadores_do_Parana.htm.

15 A Questão de Palmas, também denominada como Questão das Missões, foi um contencioso em Relações Internacionais, entre os governos da Argentina e do Brasil, entre1890 e 1895, que disputaram aquele território, hoje brasileiro.

${ }^{16}$ A descrição do engenheiro é detalhada: 78 lotes urbanos. \&0 lotes rurais na linha Iguaçu; 77, na linha Taquaral; 73, na linha Cachoeira e 25, na linha Canoas. Dos 245 lotes rurais, cerca de um terço já eram de domínio particular por título de propriedade.

${ }^{17}$ Memórias - Sebastião Edmundo Wos Saporski. Anais da comunidade brasileiropolonesa. Volume VI - Ano 1972. Curitiba - PR. 
http://www.polonesesnobrasil.com.br/Saporski/Livro/Saporski_anais.htm.

18 A colônia Palmira é da mesma região e fundada no ano de 1891, mas o engenheiro Beltrão não apresentou o número de lotes dessa colônia neste relatório.

${ }^{19}$ A primeira circunscrição comportava as colônias de Iguaçu, Canoa e Cachoeira.

20 As colônias vicinais são localizadas em estradas secundárias, ligando umas localidades a outras.

${ }^{21}$ A notícia é referida à GAZETA POLSKA w BRAZYLII, 22 de julho de 1893, nº 3, ano II.

${ }^{22}$ Citamos conforme os artigos 14, 17, 19 e 21 do estatuto da irmandade.

\section{REFERÊNCIAS BIBLIOGRAFICAS}

AMORIN, Erika; ANDRADE, Cyntia; CARDONA, Nina; UMBELINO, Jorge. Igreja rosário dos pretos: análise das contribuições culturais para o turismo étnico (afro) em Salvador-BA.

http://www.google.com.br/url?sa=t\&rct=j\&q=\&esrc=s\&source=web\&cd=8\&sqi=2\&ve $\mathrm{d}=0 \mathrm{CGcQFjAH} \& u r l=\mathrm{http} \% 3 \mathrm{~A} \% 2 \mathrm{~F} \% 2 \mathrm{Fwww} . \mathrm{tmstudies}$.net $\% 2$ Findex.php $\% 2 \mathrm{Fectms} \% 2$ Farticle\%2Fdownl. Acesso em 09/2012.

ANDREAZZA, M. L.; NADALIN, S. O. Imigração e sociedade. Curitiba: UFPR, Departamento de História, 1993.

ANTUNTES, Ricardo. O caracol e sua concha: ensaios sobre a nova morfologia do trabalho. São Paulo: Boitempo, 2005.

AZEVEDO, Célia M. Martinho de. Onda Negra Medo Branco: o negro no imaginário das elites - Século XIX. Rio de Janeiro: Paz e Terra, 1987.

BABBAR, Lara Janek. Características, transformações e adaptações da música religiosa ucraniana no Paraná. Dissertação de mestrado em Música. Universidade Federal do Paraná. Curitiba: 2008.

BAKOUR, Houda Blum. A igreja ortodoxa antioquina na cidade do Rio de Janeiro: construção e manutenção de uma identidade religiosa diaspórica no campo religioso brasileiro. Dissertação de mestrado em antropologia. Universidade Federal Fluminense. Niterói, 2007. 
BOSCHILIA, R. O cotidiano de Curitiba durante a II Guerra Mundial. Boletim Informativo da Casa Romário Martins. Curitiba: Fundação Cultural, 1995.

CARVALHO, Tatiane Valéria Rogério de. A identidade do movimento hip-hop curitibano a partir da análise do discurso de letras de música de RAP. Dissertação de mestrado em lingüística. Universidade Federal do Paraná. Curitiba, 2011.

CUNHA, Joceneide. Apontamentos sobre as Irmandades do Rosário dos Homens Pretos da Capitania de Sergipe del Rei (1750-1835). XI Congresso Luso Afrobrasileiro de Ciências Sociais. Salvador - $07-10$ de agosto de 2011. Universidade Federal da Bahia.

CZAIKOWSKI, Mariano. Palestra. XXXVII Congresso da Juventude UcraínoBrasileira, Mallet - PR.

DOUSTDAR, Neda Mohtadi. Imigração polonesa: raízes históricas de um preconceito. Dissertação de mestrado em História. Universidade Federal do Paraná. Curitiba, 1990.

ESTADO DO PARNÁ. Relatório apresentado ao governador por Francisco Gutierrez Beltrão. Curitiba: Oficina de Artes Gráfica, 1907.

GLUCHOWSKI, K. Os poloneses no Brasil. Porto Alegre: Rodzicz \& Ordakowski editores, 2005.

GORZ. André. (org.) Divisão social do trabalho e modo de produção capitalista. Porto: Publicações Escorpião, 1976.

HAINENKO, Valdemiro. Uma centelha de luz: clero diocesano no Brasil. Curitiba: Editora Kindra, 1985.

HERÉDIA, Vânia. A imigração européia no século passado: o programa de colonização no Rio Grande do Sul. In.: Revista Electrónica de Geografía y Ciencias Sociales. Universidad de $\mathrm{N}^{\mathrm{o}} 94$ (10), 1 de agosto de 2001.

IOTTI, Luiza Horn. Imigração e colonização. http://www.tjrs.jus.br. Acesso em 09/2012.

LAMB, Roberto Edgar. Uma jornada civilizadora: imigração, conflito social e segurança pública na província do Paraná - 1867 a 1882. Curitiba: Aos Quatro Ventos, 1999. 
MALHEIRO, Pedro Machado de Miranda. Providências para a jornada da Colônia dos Suissos desde o Porto do Rio de Janeiro até. à Nova Friburgo em Morro-queimado no Districto da Villa de S. Pedro de Cantagallo; dadas em conseqüência das ordens de Sua Majestade. Rio de Janeiro: Impressão Régia, 1819.

MARTINS, Karla Denise; OLIVEIRA, Gustavo de Souza. O ensino religioso no Brasil: considerações sobre o processo de cristianização.In.: Revista de C. Humanas. Vol. 9, No 1, p. 137-148, Jan./Jun. 2009.

MEMÓRIAS - Sebastião Edmundo Wos Saporski. Anais da comunidade brasileiropolonesa. Volume VI - Ano 1972. Curitiba - PR.

MOURA, Vera Lúcia Braga de. Pequenos aprendizes: assistência à infância desvalida em Pernambuco no século XIX. Dissertação de mestrado em história. Universidade Federal de Pernambuco. Recife, 2003.

NOZOE, Nelson. Sesmarias e apossamento de terras no Brasil colônia. In.: Revista Economia. Set/Dez 2006.

PROVÍNCIA DO PARANÁ - dados estatísticos e esclarecimentos para os emigrantes publicados por ordem d o ministério dos negócios da agricultura, do comércio e das finanças. Rio de Janeiro: Imprensa oficial, 1875.

SILVA, Henrique Nelson da; ASSIS, Virgínia Almoêdo de. Os oficiais mecânicos e a irmandade de São José dos quatro ofícios, pedreiros, carpinteiros, marceneiros e tanoeiros no Recife, século XVIII. I Colóquio de História da Universidade Federal Rural de Pernambuco UFRPE, Recife, Pernambuco, Brasil. Brasil e Portugal: nossa história ontem e hoje De 3 a 5 de outubro de 2007.

TRECCANI, Girolamo Domenico. O título de posse e a legitimação de posse como formas de aquisição da propriedade. http://www.pge.pa.gov.br/files/u13/ARTIGO\%206\%20\%20DR.\%20GIROLAMO\%20OKK. Acesso em 09/2012.

WACHOWCIZ, R. C. As escolas da colonização polonesa no Brasil. In Anais da Comunidade Brasileiro-Polonesa. Curitiba: op. cit. vol. VII, 1970.

\section{SITES CONSULTADOS:}


http://www.diocesepetropolis.org.br/paroquia/index.php?paroquia=2. Acesso em 09/2012.

http://www.flickr.com. Acesso em 09/2012.

http://www.hcomparada.ifcs.ufrj.br/revistahc/artigos/volume002_Num001_artigo003 Acesso em 09/2012.

http://www.corumbatai.sp.gov.br/master2.php?post=historia. Acesso em 09/2012. http://www.arquitetura.eesc.usp.br. Acesso em 09/2012.

http://www.gazetadopovo.com.br/vidaecidadania/conteudo.phtml?tl=1\&id=1217660\&ti $\mathrm{t}=$ De-capela-a-basilica. 28/01/2012.

http://www.diocesepontagrossa.com.br. Acesso em 09/2012.

http://catedralguarapuava.webnode.com.br/news/paroquia\%20divino\%20espirito\%20sa nto\%20de\%20pinh\%C3\%A3o/ Acesso em 08/2012.

http://tvondalivre.com/2012/regularizada-documentacao-da-igreja-matriz-de-palmeira/. Acesso em 08/2012.

http://catedraluniao.com/. Acesso em 10/2012.

http://www.infosaojoaobatista.blogspot.com.br/p/historia. Acesso em 10/2012.

http://www.cmsaojoaodotriunfo.pr.gov.br/history. Acesso em 10/2012.

http://psaomateus.com Acesso em 10/2012

http://www.corumbatai.sp.gov.br/master2.php?post=historia. Acesso em 10/2012. 